\title{
Empirical Analysis of the Influence of Inventory Management on Financial Performance in the Food Industry in Poland
}

\author{
Zbigniew Golas, Anna Bieniasz \\ Poznan University of Life Sciences \\ Wojska Polskiego 28, 60-637 Poznan, Poland \\ E-mail.zbyszekg@up.poznan.pl,bieniasz@up.poznan.pl
}

cross $^{\text {ref }}$ http://dx.doi.org/10.5755/j01.ee.27.3.5933

\begin{abstract}
The article presents the results of the analysis of changes in inventory management and the results of verification of cause and effect relationships between the results of inventory management and the financial performance of enterprises. The research was conducted on the branches (subsectors) of the food industry in Poland in 2005-2010. The research is based on the econometric analysis of the influence of the length of inventory cycles (in total, materials, production in progress, finished goods, commodities) on financial performance of branches measured with return on sales, assets and equity. The research proved that the effectiveness of inventory management measured with the length of inventory cycles is strongly diversified in the system of branches of the food industry. However, in general in 2005-2010 the inventory cycles were significantly reduced, which points to higher effectiveness of management of those assets. Moreover, on the basis of regression models the improvement in the effectiveness of inventory management measured with the length of total inventory cycles and discrete cycles was found to be positively correlated with profitability. The presented results are the first systematised analysis of the correlations between the results of inventory management and financial performance in the food industry in Poland.
\end{abstract}

Keywords: Inventory Cycle, Return on Assets, Return on Equity, Financial Performance, Food Industry, Poland.

\section{Introduction}

Inventory management is one of the major areas of operations management. It gives a possibility to meet the reported demand at the appropriate level and to avoid production surplus and deficit by inventory monitoring and forecasting. When discussing the issues of inventory management effectiveness, apart from the aspects related to demand and logistics, it is somehow natural to study the financial aspect, related to the necessity to maintain the inventory and to the cost it generates. Inventory maintenance results from numerous premises, which are diversified, depending on the inventory type (Kempny, 1995; KisperskaMoron, 1995; Kolias et al., 2011; Sierpinska \& Wedzki, 1997). The maintenance of material and raw material inventory involves the need to ensure rhythmicity of production, potential benefits of the scale of production and supplies, reduced risk related to the uncertainty of supplies and delivery time, pursuit of limiting the influence of seasonality of supplies and seasonality of demand. As far as the inventory of finished products is concerned, the primary premise is to ensure sales continuity, the lack of which results in reduced profit from sales, lower reputation of the company and, in consequence, has negative influence on the competitive situation of an enterprise. However, maintaining inventory involves different costs. The most important of these are: costs of warehousing, loading and transport, insurances, costs resulting from inventory losses, costs of loss of order volume discounts, stockout costs and capital costs (lost benefits) resulting from freezing capital in inventory.

The high rank of the problem of effective inventory management also results from its share in the assets structure. In most enterprises, except the financial sector and services, inventory is a considerable part of both current assets and total assets. A characteristic example of this is retail, where these relations are the highest. According to the studies by Gaur et al. (2005), in 2003 in retail in the USA inventory made $36 \%$ of total assets value and $53 \%$ of current assets value. Kolias et al. (2011) point to similar relations and report the fact that between 2000 and 2005 in retail in Greece analogical shares had the average values of $38 \%$ and $51 \%$ respectively. Inventory is also a considerable part of assets in industrial enterprises. For example, in 2010 in such countries as Austria, Germany, Spain, France, Italy and Portugal the share of inventory in the value of total assets and current assets reached a similar level of $15 \%$ and $30 \%$ respectively $(\mathrm{BACH}$, 2011). However, the analyzed indicators in food industries of the listed above countries have been on expressly higher levels (average $17 \%$ and $33 \%$ ), especially in France, where the share of inventory in both total assets and current assets have been $22 \%$ and $40 \%$ respectively (BACH, 2011).

The issue of inventory management in food industry is also important for other reasons, which generally don't appear in the non-food industry branches. In the food industry enterprises (especially in the food production, in lesser extent in the beverages production) it is necessary to store the raw materials needed in the production for a longer period of time. The raw materials should be stored in environment preventing it from losses caused by various chemical, physical or microbiological factors. It results mainly from the fact that the seasonality of agricultural production requires accumulating substantial amount of inventory needed for the continuity of the production in the reasonable short time. Moreover, the materials used in the food production technology have limited shelf-life, which is relevant factor affecting both production costs and its technological value. 
The aim of this article is to verify the cause and effect correlations between the effectiveness of inventory management and financial performance. As Capkun et al. (2009) stress, so far this type of research has been limited and usually it has not allowed for the internal structure of inventory. The article presents thorough research results, in which the food industry sector (28 subsectors) should be considered as the subject of the research and the inventory management's effectiveness in years 2005-2010 should be considered as the object of the study. The results of the research should be considered as useful tool in the process of operational management or finance management. It might be helpful for managers in the decision processes concerning issues related to the inventory level formation and identifying reasons for differences in its levels. The structure of the article is as follows. After the introduction (1) there is a literature review (2), where the main focus is on the methodological aspects and results of empirical studies on the influence of effective inventory management on financial performance of branches. The next subchapter (3) includes the research hypotheses and presents information concerning the source material and describes the applied methods. The content of the next part of the article (4) is a characterisation of inventory management in the Polish food sector. It discusses changes in the share of inventory in assets, changes in the internal structure of inventory, and there is a comparative analysis of the length of inventory cycles in the system of branches of the food industry. Next, (5) there is a presentation of the results of estimation of regression models, which enable determination of the strength and direction of the influence of the length of inventory cycles on profitability. The last section (6) of the article contains conclusions.

\section{Literature Review}

It is possible to notice that economic literature provides a wide range of studies analysing the influence of inventory management on the financial situation of enterprises. This issue has often been analysed in the aspect of working capital effectiveness, where the influence of the policy of management of receivables and current liabilities has been studied along with the influence of the inventory management policy on financial performance. In general, most of those studies (e.g. Deloof, 2003; Dong \& Su, 2010; Lazaridis \& Tryfonidis, 2006; Padachi 2006; Ramachandran \& Janakiraman, 2009; Raheman et al., 2010) point to the negative influence of prolongation of inventory cycles (low inventory turnover) on the financial performance measured with different profitability ratios.

High interest in the issue resulted in numerous publications in the literature concerning the economics of production, operations management and logistics. As results from the studies by Kolias et al. (2011) on the panel of retail companies in Greece and from the studies by Gaur et al. (2005) as well as by Roumiantsev and Netessine (2007) on retail in the USA, there is a negative correlation between the increase in inventory turnover and return on sales. On the other hand, the study by Shah and Shin (2007) points to the reverse correlation in the retail sector in the USA. According

\footnotetext{
1 The Polish Classification of Economic Activities PKD 2007 is compatible with the classification system used in the European Union (NACE Rev.2). As
}

to it, higher inventory productivity leads to higher return on sales in this sector.

Usually studies conducted on industrial sectors, branches and enterprises indicate measurable financial profits resulting from an increase in inventory turnover (reducing the length of inventory cycles). If we limit our choice to publications from the last ten years, above all it is necessary to list the studies which positively verified the influence of improvement in inventory management on the financial performance of the industry measured with: return on sales (Capkun et al., 2009; Eroglu \& Hofer, 2011; Koumanakos, 2008; Roumiantsev \& Netessine, 2007; Shah \& Shin, 2007), return on invested capital (Cannon, 2008; Obermaier \& Donhauser, 2009), return on assets (Cannon, 2008), longterm rate of return on shares (Chan et al., 2005). However, apart from the research by Capkun et al. (2009), the aforementioned studies analysed the correlation between inventory productivity and financial performance in terms of total inventory, thus abstracting from its internal structure.

The aim of this article is to bridge this gap and it presents the results of modelling studies on the Polish food industry with regard to inventory types. The following ratios were used in the modelling: raw material cycle, semi-finished products and work-in-process cycle, finished products cycle and goods cycle. As Capkun et al. (2009) rightly stress, studies on the correlations between financial performance and productivity of individual inventory components are poorly represented in specialist literature.

\section{Research Hypotheses, Source Material and Methodological Aspects}

The correlation between the results of inventory management and financial performance of enterprises, which has been proved in numerous studies, justifies the following hypotheses:

$\mathrm{H} 1 \mathrm{a}$ - the length of the total inventory cycle is diversified in time and in the system of food industry branches,

$\mathrm{H} 1 \mathrm{~b}$ - shortening/lengthening the total inventory cycle is positively/negatively correlated with financial performance of enterprises in the food industry,

$\mathrm{H} 2 \mathrm{a}$ - the length of inventory component cycles (raw materials, semi-finished products and work-in-process, finished products and goods) is diversified in time and in the system of food industry branches,

$\mathrm{H} 2 \mathrm{~b}$ - shortening/lengthening inventory component cycles (raw materials, semi-finished products and work-inprocess, finished products and goods) is positively /negatively correlated with financial performance of enterprises in the food industry.

In order to verify the aforementioned hypotheses the authors used unpublished statistics of the Central Statistical Office (CSO) in the system of branches (subsectors) of the food industry in Poland. The research comprised 28 branches from the years 2005-2010, including 23 branches in food production and 5 branches in beverage production, which were identified according to the System of Polish Classification of Economic Activities 2007 (The Polish ... 2011) $)^{1}$.

far as the food industry is concerned, the Polish Classification of Economic Activities PKD 2007 groups enterprises into 32 classes (subsectors), i.e. into 25 classes in food production and in 7 classes in beverage production. Due to the 
Five ratios of inventory management assessment and three financial effectiveness categories were applied in the analysis of the correlations between inventory management effectiveness and financial effectiveness at the branch level. Inventory management was assessed by means of the total inventory cycle ratio $\left(\mathrm{TINC}_{\mathrm{j}, \mathrm{t}}\right)$ and discrete ratios, i.e. the raw material cycle $\left(\mathrm{RMC}_{\mathrm{j}, \mathrm{t}}\right)$, the semi-finished products inventory and work-in-process cycle $\left(\mathrm{SFPC}_{\mathrm{j}, \mathrm{t}}\right)$, the finished products inventory cycle $\left(\mathrm{FPC}_{\mathrm{j}, \mathrm{t}}\right)$ and the goods cycle $\left(\mathrm{GC}_{\mathrm{j}, \mathrm{t}}\right)$. The ratios were calculated according to the following formulas:

$$
\begin{aligned}
& R M C_{j, t}=
\end{aligned}
$$

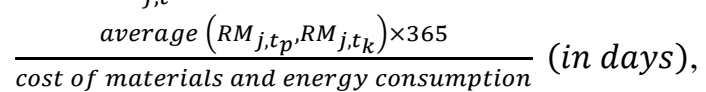

$$
\begin{aligned}
& S F P C_{j, t}=\frac{\text { average }\left(S F P_{j, t_{p}}, S F P_{j, t_{k}}\right) \times 365}{\text { operating cost }}(\text { in days }),
\end{aligned}
$$

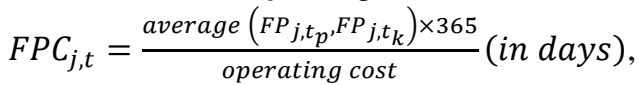

$$
\begin{aligned}
& G C_{j, t}=\frac{\text { average }\left(G_{j, t_{p}}, G_{j, t_{k}}\right) \times 365}{\text { value of goods and materials sold }}(\text { in days }), \\
& T I N C_{j, t}=R M C_{j, t}+S F P C_{j, t}+F P C_{j, t}+ \\
& G C_{j, t} \text { (in days), }
\end{aligned}
$$

where:

$R M_{j, t_{p}}, R M_{j, t_{k}}$ - the value of inventory of raw materials in subsector $\mathrm{j}$ at the beginning $\left(\mathrm{t}_{\mathrm{p}}\right)$ and end $\left(\mathrm{t}_{\mathrm{k}}\right)$ of year $\mathrm{t}$,

$S F P_{j, t_{p}}, S F P_{j, t_{k}}$ - the value of inventory of semi-finished products and work in progress in subsector $\mathrm{j}$ at the beginning $\left(\mathrm{t}_{\mathrm{p}}\right)$ and end $\left(\mathrm{t}_{\mathrm{k}}\right)$ of year $\mathrm{t}$,

$F P_{j, t_{p}}, F P_{j, t_{k}}$ - the value of inventory of finished products in subsector $\mathrm{j}$ at the beginning $\left(\mathrm{t}_{\mathrm{p}}\right)$ and end $\left(\mathrm{t}_{\mathrm{k}}\right)$ of year $\mathrm{t}$,

$G_{j, t_{p}}, G_{j, t_{k}}$ - the value of inventory of goods in subsector $\mathrm{j}$ at the beginning $\left(\mathrm{t}_{\mathrm{p}}\right)$ and end $\left(\mathrm{t}_{\mathrm{k}}\right)$ of year $\mathrm{t}$.

On the other hand, financial effectiveness of food industry branches was assessed by means of the operating return on sales $\left(\mathrm{ROS}_{\mathrm{j}, \mathrm{t}}\right)$, return on operating assets $\left(\mathrm{ROA}_{\mathrm{j}, \mathrm{t}}\right)$ and return on equity $\left(\mathrm{ROE}_{\mathrm{j}, \mathrm{t}}\right)$, which were calculated according to the following formulas:

$$
\begin{aligned}
& R O S_{j, t}=\frac{E B I T D A_{j, t} \times 100}{O R_{j, t}}, R O A_{j, t}=\frac{E B I T D A_{j, t} \times 100}{\operatorname{average}\left(O A_{j, t_{p}}, O A_{j, t_{k}}\right)}, \\
& R O E_{j, t}=\frac{E B T_{j, t} \times 100}{\text { average }\left(E_{j, t_{p}}, E_{j, t_{k}}\right)},
\end{aligned}
$$

where:

$E B I T D A_{j, t}$ - operating profit + depreciation in subsector $\mathrm{j}$ in year $\mathrm{t}$,

$O R_{j, t}$ - operating revenues (revenues from sales of products, goods and materials + other operating revenues) in subsector $\mathrm{j}$ in year $\mathrm{t}$,

$O A_{j, t_{p}}, O A_{j, t_{k}}$ - operating assets (tangible fixed assets + intangible assets + long term receivables + long-term deferred charges and accruals or long-term prepayments + short-term receivables + inventory) in subsector $\mathrm{j}$ at the beginning $\left(\mathrm{t}_{\mathrm{p}}\right)$ and end $\left(\mathrm{t}_{\mathrm{k}}\right)$ of year $\mathrm{t}$,

$E B T_{j, t}$ - earnings before tax in the subsectors $\mathrm{j}$ in year $\mathrm{t}$,

$E_{j, t_{p}}, E_{j, t_{k}}$ - equity in subsector $\mathrm{j}$ at the beginning $\left(\mathrm{t}_{\mathrm{p}}\right)$ and end $\left(\mathrm{t}_{\mathrm{k}}\right)$ of year $\mathrm{t}$.
Regression analysis was applied in order to determine the strength and direction of the influence of the results of inventory management, measured with the length of cycles, on financial effectiveness, measured with three rates of return. For each profitability category $\left(\operatorname{ROS}_{\mathrm{j}, \mathrm{t}}, \mathrm{ROA}_{\mathrm{j}, \mathrm{t}}\right.$, $\mathrm{ROE}_{\mathrm{j}, \mathrm{t}}$ ) parameters of six regression equations were assessed. They allowed for: the total inventory cycle individually $\left(\mathrm{TINC}_{\mathrm{j}, \mathrm{t}}\right)$, each discrete inventory cycle individually $\left(\mathrm{RMC}_{\mathrm{j}, \mathrm{t}}, \quad \mathrm{SFPC}_{\mathrm{j}, \mathrm{t}}, \quad \mathrm{FPC}_{\mathrm{j}, \mathrm{t}}, \quad \mathrm{GC}_{\mathrm{j}, \mathrm{t}}\right)$ and simultaneously, all types of inventory cycles without the total inventory cycle. This procedure enables analyses at different degrees of inventory aggregation and thus provides greater analytical possibilities. Research projects conducted in developed countries were used as a pattern to follow in tests of correlations between financial performance and the results of inventory management (see Cannon, 2008; Capkun et al., 2009; Chan et al., 2005; Chan et al., 1988; Eroglu \& Hofer, 2011; Gaur et al., 2005; Koumanakos, 2008; Roumiantsev \& Netessine, 2007; Sine et al., 2003). The inclusion of those studies and the authors' own concepts resulted in the construction and estimation of the following regression models:

$$
\begin{aligned}
& R O S_{j, t}=a_{0}+b_{1} I N C_{i, j, t}+b_{2} V_{A O R_{j, t}}+b_{3} E_{B I T V} A_{j, t} \\
& +b_{4} R O S_{j, t-1}+b_{5} B R_{k, t}+b_{6} T_{t}+\varepsilon \\
& R O A_{j, t}=a_{0}+b_{1} I N C_{i, j, t}+b_{2} R O S_{j, t}+b_{3} R O A_{j, t-1} \\
& +b_{4} B R_{k, t}+b_{5} T_{t}+\varepsilon \\
& R O E_{j, t}=a_{0}+b_{1} I N C_{i, j, t}+b_{2} R O S_{j, t}+b_{3} I C E_{j, t} \\
& +b_{4} E B T E B I T_{j, t}+b_{5} R O E_{j, t-1} \\
& +b_{6} B R_{k, t}+b_{7} T_{t}+\varepsilon
\end{aligned}
$$

where:

$a_{0}$ - constant of the equation,

$I N C_{i, j, t} \quad$ - i-th inventory cycle $T I N C_{j, t}, R M C_{j, t}$, $S F P C_{j, t}, F P C_{j, t}, G C_{j, t}$ in subsector $\mathrm{j}$ in year $\mathrm{t}$,

$V A O R_{j, t}$ - ratio of value added $\left(V A_{j, t}\right)$ to operating revenues $\left(O R_{j, t}\right)$ in subsector $\mathrm{j}$ in year $\mathrm{t}$,

$\left(E B I T V A_{j, t}\right)$ - ratio of earnings before interest and taxes $\left(E B I T_{j, t}\right)$ to value added $\left(V A_{j, t}\right)$ in subsector $\mathrm{j}$ in year $\mathrm{t}$,

$\left(B R_{k, t}\right)$ - binary variable $(\mathrm{k}=1$ for subsectors manufacturing food products, $\mathrm{k}=0$ for subsectors manufacturing beverages in year $\mathrm{t}$ ),

$\left(T_{t}\right)$ - time variable $(\mathrm{t}=1 \ldots \ldots 6)$,

$\left(I C E_{j, t}\right)$ - ratio of invested capital $\left(I C_{j, t}\right)$ to equity $\left(E_{j, t}\right)$ in subsector $\mathrm{j}$ in year $\mathrm{t}$,

$\left(E B T E B I T_{j, t}\right)$ - ratio of earnings before tax $\left(E B T_{j, t}\right)$ to earnings before interest and taxes $\left(E B I T_{j, t}\right)$ in subsector $\mathrm{j}$ in year $\mathrm{t}$,

$\left(R_{O S} S_{j-1}\right)$ - operating return on sales in subsector $\mathrm{j}$ in year $\mathrm{t}-1$,

$\left(R O A_{j, t-1}\right)$ - return on operating assets in subsector $\mathrm{j}$ in year $\mathrm{t}-1$,

$\left(R O E_{j, t-1}\right)$ - return on equity in subsector $\mathrm{j}$ in year $\mathrm{t}-1$, $\varepsilon$ - random component.

The analysis of the structure of the aforementioned regression models points to the fact that in search of 
correlations between profitability and the results of inventory management apart from the variables describing the length of inventory cycles $\left(\mathrm{TINC}_{\mathrm{j}, \mathrm{t}}, \mathrm{RMC}_{\mathrm{j}, \mathrm{t}}, \mathrm{SFPC}_{\mathrm{j}, \mathrm{t}}\right.$, $\mathrm{FPC}_{\mathrm{j}, \mathrm{t}}, \mathrm{GC}_{\mathrm{j}, \mathrm{t}}$ ) other variables were also assumed. In all the models the binary variable $\left(\mathrm{BR}_{\mathrm{k}, \mathrm{t}}\right)$ was applied, which differentiated the researched grouping according to the branches of the food industry (food or beverage production), and the time variable $\left(\mathrm{T}_{\mathrm{t}}\right)$, which determined the influence of time. Apart from that, in each regression model the authors applied the variables which allowed for the specific character of a given category of profitability. For the return on sales $\left(\mathrm{ROS}_{\mathrm{j}, \mathrm{t}}\right)$ value added ratio $\left(\mathrm{VAOR}_{\mathrm{j}, \mathrm{t}}\right)$ and the ratio of operating profit to value added $\left(\right.$ EBITVA $\left._{\mathrm{j}, \mathrm{t}}\right)$ were applied, which generally define cost effectiveness. On the other hand, in the return on assets model $\left(\mathrm{ROA}_{\mathrm{j}, \mathrm{t}}\right)$ the authors were guided by the premises resulting from the theory of finances (Brigham \& Gapenski, 1993; Hawawini \& Viallet, 2002), in view of which return on assets is a function of the return on sales $\left(\operatorname{ROS}_{\mathrm{j}, \mathrm{t}}\right)$ and assets turnover, which in this case is represented by the ratios of inventory cycles. Similar premises were decisive for the construction of the return-onequity model $\left(\mathrm{ROE}_{\mathrm{j}, \mathrm{t}}\right)$. The rate of return on equity is functionally determined by: assets turnover $\left(\mathrm{INC}_{\mathrm{i}, \mathrm{j}, \mathrm{t}}\right)$, return on sales $\left(\operatorname{ROS}_{\mathrm{j}, \mathrm{t}}\right)$, the so-called equity multiplier $\left(\mathrm{ICE}_{\mathrm{j}, \mathrm{t}}\right)$ and financial costs ratio $\left(\mathrm{EBTEBIT}_{\mathrm{j}, \mathrm{t}}\right)$. Moreover, profitability ratios with time delay were applied $\left(\operatorname{ROS}_{\mathrm{j}, \mathrm{t}-1}, \mathrm{ROA}_{\mathrm{j}, \mathrm{t}-1}\right.$, $\left.\mathrm{ROE}_{\mathrm{j}, \mathrm{t}-1}\right)$. They provide information about the influence of previous financial performance on the current results. These ratios are usually correlated with the dependent variable and they are often used in research practice (Capkun et al., 2008; Chan et al., 2005, Chan et al., 1988; Sine et al., 2003).

\section{Inventory Level and Results of Inventory Management in the Food Industry}

Table 1 shows the basic structural determinants of inventory in the food industry in total and separately for food production and beverage production. As results from their analysis, between 2005 and 2010 there was a relatively visible and favourable tendency of reduction of the share of inventory in total assets and current assets. In the entire food sector the shares dropped down from $16.2 \%$ to $13.1 \%$ and from $34.5 \%$ to $30.4 \%$ respectively, i.e. by $4.3 \%$ and $2.5 \%$ on annual average. The same direction of changes can be observed in food and beverage production. However, in these sectors of the food industry there is diversification both in the rank of inventory, measured with its share in the assets, and in the dynamics of changes (Table 1).

In food production, mostly due to the technological and organisational conditions of production processes inventory has a considerably larger share in total assets (14.2-18.2\%) and current assets (32.3-37.5 \%) than in beverage production, where these shares are about half smaller. In general, this means that the significance of inventory is definitely higher for the financial situation of branches in food production than in beverage production. Apart from that, the branches of the food sector differ significantly in the dynamics of changes in the share of inventory in total assets and current assets.

On annual average between 2005 and 2010 these shares in food production decreased by $4.8 \%$ and $2.9 \%$ respectively, whereas in beverage production the analogical indexes were $-2.0 \%$ and $-0.5 \%$. Thus, in general, in spite of rather visible differences in both divisions there was a permanent and positive tendency of changes.

However, it does not always result in measurable economic and financial profits. First of all, reduced inventory may result in higher value of enterprises due to reduced inventory costs. Second of all, this value may also be reduced due to expenses on unpredictable events. Third of all, it increases the risk of financial liquidity due to reduced working capital.

The conducted studies also point to differences in the internal inventory structure of divisions of the food industry (Table 1). Although in both divisions the dominant inventory components are materials and finished products, it is possible to notice that in comparison with beverage production in food production the share of materials is visibly lower, whereas the share of finished products is definitely higher. Thus, in general, it is possible to state that effective management of material inventory and finished products inventory is of primary importance for the financial situation of food enterprises. It is also worth stressing that although both of these divisions have a relatively stable internal structure of inventory, there is a contrary tendency of changes in them. In food production the increase in the share of materials corresponded to the decrease in the share of finished products, whereas in beverage production the situation was the opposite, i.e. the share of finished products in inventory increased and the share of materials decreased. However, the changes in this area were not dynamic. Therefore, it is possible to conclude that they did not deteriorate the effectiveness of inventory management. As it has been indicated before, in the period under analysis the inventory had an increasingly smaller share in the assets, which, with a dynamic increase in the income of the food sector, resulted in improved effectiveness.

Further information on this topic provide the data in Table 2, indicating the industry diversity and dynamics of changes in inventory management efficiency measured by the length of inventory cycles.

Between 2005 and 2010 the average length of inventory cycle in the entire food sector was only 87 days and every year on average the cycle was shortened by 1.6 $\%$. During that period the increase in the effectiveness of total inventory management resulted from the improvement in the effectiveness of management of all inventory types except semi-finished products and work-in-process. It is a very favourable situation because the reduction of cycles time concerned materials $(-2.1 \%)$, finished products $(-1.7$ $\%)$ and goods $(-1.8 \%)$, i.e. those types of inventory which have the strongest influence on the length of the total inventory cycle. Similar conclusions can be drawn from the analysis of changes in the length of the total cycle and discrete cycles in food production, but certain differences can be noticed in beverage production. In the beverage division the reduction of inventory cycle time was relatively more dynamic. Besides, it also concerned semi-finished products and work-in-process along with a relatively stable level of the finished products cycle.

The data included in Table 2 also point to a strong inter-branch diversification of the length of inventory cycles and dynamics of their changes. In the period under analysis 
the longest total inventory cycle was observed in: sugar production (10.81), production of homogenised food preparations and dietetic food (10.86), wine from grape (11.02), other processed and preserved fruit and vegetables (10.39) and oil production (10.41). In those branches the inventory turnover was characterised by a long cycle of 4-5 months. On the other hand, the shortest total inventory cycle was in the branches related with to meat processing
(10.11-13), production of bread, fresh pastry goods and cakes (10.71) and milk processing (10.51). Here, the inventory cycle usually did not exceed 1 month. The nearly fivefold difference in the length of the inventory cycle between those branches is caused by a similar scale of differences in discrete cycles.

Table 1

Significance of inventory in the food industry in Poland in 2005-2010 (\%) ${ }^{1}$

\begin{tabular}{|c|c|c|c|c|c|c|c|c|}
\hline Specification & 2005 & 2006 & 2007 & 2008 & 2009 & 2010 & $\bar{x}$ & $\Delta \%$ \\
\hline \multicolumn{9}{|c|}{ Total food industry } \\
\hline share of inventory in total assets & 16.2 & 15.8 & 16.2 & 15.1 & 13.8 & 13.1 & 15.0 & -4.3 \\
\hline share of inventory in current assets & 34.5 & 33.5 & 34.5 & 33.1 & 31.0 & 30.4 & 32.8 & -2.5 \\
\hline share of materials in inventory & 38.1 & 39.1 & 39.1 & 40.6 & 40.0 & 40.3 & 39.5 & 1.2 \\
\hline $\begin{array}{l}\text { share of semi-finished products and work in progress in } \\
\text { inventory }\end{array}$ & 11.1 & 11.4 & 12.2 & 12.7 & 13.3 & 13.4 & 12.3 & 3.9 \\
\hline share of finished products in inventory & 42.9 & 41.1 & 40.4 & 38.3 & 37.8 & 36.3 & 39.4 & -3.3 \\
\hline share of goods in inventory & 7.0 & 7.8 & 7.0 & 7.2 & 8.1 & 8.9 & 7.6 & 5.1 \\
\hline share of advances for deliveries in inventory & 0.9 & 0.7 & 1.3 & 1.2 & 0.9 & 1.0 & 1.0 & 2.0 \\
\hline \multicolumn{9}{|c|}{ Manufacture of food products } \\
\hline share of inventory in total assets & 18.2 & 17.7 & 18.2 & 17.0 & 15.4 & 14.2 & 16.7 & -4.8 \\
\hline share of inventory in current assets & 37.5 & 36.4 & 37.2 & 35.8 & 34.0 & 32.3 & 35.5 & -2.9 \\
\hline share of materials in inventory & 36.7 & 38.0 & 38.0 & 39.5 & 39.3 & 40.2 & 38.6 & 1.8 \\
\hline $\begin{array}{l}\text { share of semi-finished products and work in progress in } \\
\text { inventory }\end{array}$ & 10.8 & 11.2 & 12.2 & 12.9 & 13.6 & 13.9 & 12.4 & 5.2 \\
\hline share of finished products in inventory & 44.7 & 42.4 & 41.6 & 39.4 & 38.7 & 36.9 & 40.5 & -3.8 \\
\hline share of goods in inventory & 6.9 & 7.8 & 7.0 & 7.0 & 7.4 & 8.1 & 7.3 & 3.4 \\
\hline share of advances for deliveries in inventory & 1.0 & 0.6 & 1.1 & 1.1 & 0.9 & 1.0 & 0.9 & -0.4 \\
\hline \multicolumn{9}{|c|}{ Manufacture of beverages } \\
\hline share of inventory in total assets & 8.4 & 7.7 & 8.4 & 8.0 & 7.5 & 7.6 & 7.9 & -2.0 \\
\hline share of inventory in current assets & 20.3 & 19.2 & 21.0 & 20.7 & 18.4 & 19.9 & 19.9 & -0.5 \\
\hline share of materials in inventory & 50.3 & 49.3 & 48.4 & 49.0 & 45.1 & 41.6 & 47.2 & -3.7 \\
\hline $\begin{array}{l}\text { share of semi-finished products and work in progress in } \\
\text { inventory }\end{array}$ & 13.9 & 12.9 & 11.7 & 10.9 & 10.3 & 9.6 & 11.4 & -7.0 \\
\hline share of finished products in inventory & 27.4 & 28.7 & 29.5 & 29.4 & 30.6 & 30.7 & 29.4 & 2.4 \\
\hline share of goods in inventory & 7.8 & 8.1 & 7.6 & 9.1 & 13.4 & 16.2 & 9.9 & 15.6 \\
\hline share of advances for deliveries in inventory & 0.7 & 1.0 & 2.7 & 1.5 & 0.6 & 1.8 & 1.2 & 22.0 \\
\hline
\end{tabular}

${ }^{1} \bar{x}$ - average for the years $2005-2010, \Delta \%$ - average annual change in 2005-2010.

Source: own calculations based on unpublished CSO data.

In branches with high inventory turnover the cycles of raw materials, finished products and goods did not exceed 15 days, whereas in the branches with low inventory turnover the cycles were usually several times longer. It seems that the causes of this situation should be sought not only in the technological conditions but also in the organization of production processes. In spite of generally dynamic technological progress many enterprises of the food sector are characterised by the absence of systemic approach to inventory management. In practice, this makes optimization of its level impossible and in consequence, it generates excessive costs and reduces profit. However, an optimistic forecast is generated by the ratios of the dynamics of changes in inventory cycles. The data presented in Table 2 show that in the vast majority of branches the total inventory cycle and discrete cycles are reduced. This trend of changes definitely points to a systematic increase in the effectiveness of inventory management, which should be reflected by improved financial effectiveness. 
Table 2

The length and dynamic of inventory cycles changes in the food industry in Poland in 2005-2010

\begin{tabular}{|c|c|c|c|c|c|c|c|c|c|c|}
\hline \multirow{3}{*}{$\underset{2^{2}}{\text { NACE. Rev. }}$} & \multicolumn{10}{|c|}{ Inventory cycle (days) } \\
\hline & \multicolumn{2}{|c|}{ TINC } & \multicolumn{2}{|c|}{ RMC } & \multicolumn{2}{|c|}{ SFPC } & \multicolumn{2}{|c|}{ FPC } & \multicolumn{2}{|c|}{ GC } \\
\hline & $\bar{x}$ & $\Delta \%$ & $\bar{x}$ & $\Delta \%$ & $\bar{x}$ & $\Delta \%$ & $\bar{x}$ & $\Delta \%$ & $\bar{x}$ & $\Delta \%$ \\
\hline \multicolumn{11}{|c|}{ Total food industry } \\
\hline $10+11$ & 86.8 & -1.6 & 33.6 & -2.1 & 4.3 & 3.3 & 15.2 & -1.7 & 33.7 & -1.8 \\
\hline \multicolumn{11}{|c|}{ Manufacture of food products } \\
\hline $10.11 \div 90$ & 84.2 & -1.5 & 33.8 & -1.9 & 4.3 & 5.8 & 16.3 & -1.9 & 29.8 & -1.9 \\
\hline 10.11 & 24.1 & 5.4 & 5.0 & 5.7 & 2.8 & -1.7 & 4.5 & 0.2 & 11.8 & 9.6 \\
\hline 10.12 & 21.6 & 0.1 & 4.9 & -0.2 & 2.1 & -1.8 & 6.9 & -4.9 & 7.7 & 5.9 \\
\hline 10.13 & 23.7 & 1.1 & 10.3 & -1.2 & 3.2 & -3.3 & 4.0 & 1.7 & 6.2 & 6.9 \\
\hline 10.20 & 93.1 & -3.3 & 23.0 & -0.5 & 2.2 & 10.1 & 8.6 & -5.1 & 59.3 & -4.5 \\
\hline 10.31 & 66.0 & -0.3 & 27.9 & 0.7 & 3.0 & -2.1 & 13.0 & 7.9 & 22.1 & -5.6 \\
\hline 10.32 & 118.9 & 5.7 & 32.0 & 5.7 & 17.2 & 13.5 & 36.5 & -3.1 & 33.3 & 10.6 \\
\hline 10.39 & 145.0 & 1.2 & 23.9 & 0.4 & 18.3 & 2.6 & 46.4 & -1.8 & 56.4 & 3.4 \\
\hline 10.41 & 134.7 & -9.6 & 109.8 & -10.2 & 7.3 & -1.5 & 5.8 & -4.1 & 11.7 & -15.8 \\
\hline 10.42 & 116.7 & -9.6 & 92.3 & -10.2 & 10.9 & -1.5 & 5.7 & -4.1 & 7.7 & -15.8 \\
\hline 10.51 & 34.5 & -1.8 & 9.9 & -2.2 & 4.6 & -1.8 & 6.8 & 1.8 & 13.2 & -2.9 \\
\hline 10.52 & 84.4 & 6.1 & 30.6 & 10.1 & 0.5 & 58.1 & 16.7 & 10.0 & 36.6 & 1.2 \\
\hline 10.60 & 81.7 & -1.2 & 44.7 & -7.9 & 2.0 & -7.9 & 10.0 & -0.5 & 25.0 & 10.9 \\
\hline 10.71 & 31.4 & -1.3 & 14.5 & -2.0 & 0.5 & -6.7 & 1.6 & 0.0 & 14.9 & -0.5 \\
\hline 10.72 & 44.4 & -2.4 & 20.5 & -4.5 & 0.4 & -8.4 & 7.5 & 3.6 & 16.0 & -2.4 \\
\hline 10.73 & 74.2 & -3.7 & 38.9 & -4.7 & 1.1 & -22.5 & 11.1 & 2.7 & 23.1 & -4.0 \\
\hline 10.81 & 173.0 & -3.2 & 16.6 & 16.1 & 5.4 & 132.8 & 117.4 & -6.9 & 33.6 & -3.0 \\
\hline 10.82 & 74.9 & -4.8 & 32.2 & -4.8 & 3.1 & -4.5 & 8.0 & -2.4 & 31.6 & -5.4 \\
\hline 10.83 & 122.5 & -3.8 & 58.3 & -4.6 & 3.6 & 13.0 & 7.9 & 1.8 & 52.7 & -4.7 \\
\hline 10.84 & 93.4 & 2.7 & 36.8 & -4.4 & 1.3 & 15.0 & 9.5 & 7.1 & 45.7 & 7.0 \\
\hline 10.85 & 78.8 & 1.9 & 33.4 & -4.9 & 3.3 & 29.9 & 13.5 & 2.5 & 28.7 & 7.7 \\
\hline 10.86 & 161.4 & -12.7 & 51.6 & 4.1 & 4.8 & -53.2 & 18.1 & -1.2 & 86.9 & -26.1 \\
\hline 10.89 & 85.9 & 0.1 & 31.2 & 2.3 & 1.4 & 12.0 & 10.9 & -1.7 & 42.5 & -1.2 \\
\hline 10.90 & 53.1 & -0.9 & 28.8 & -3.1 & 0.7 & 0.4 & 4.1 & -2.9 & 19.5 & 2.1 \\
\hline \multicolumn{11}{|c|}{ Manufacture of beverages } \\
\hline $11.01 \div 07$ & 98.6 & -2.0 & 32.9 & -2.9 & 4.2 & -7.1 & 10.2 & 0.6 & 51.3 & -1.4 \\
\hline 11.01 & 91.0 & -8.8 & 43.2 & -2.1 & 2.4 & -10.7 & 3.5 & -1.1 & 41.9 & -18.3 \\
\hline 11.02 & 160.2 & -3.9 & 35.7 & -2.5 & 6.5 & -6.8 & 16.3 & -3.9 & 101.6 & -4.2 \\
\hline 11.03 & 123.0 & 0.0 & 39.7 & -0.8 & 9.5 & -6.8 & 19.6 & 4.9 & 54.1 & 0.5 \\
\hline 11.05 & 57.7 & 8.4 & 20.9 & -2.9 & 2.3 & -5.2 & 2.7 & 3.4 & 31.7 & 16.3 \\
\hline 11.07 & 61.1 & -1.8 & 25.1 & -7.8 & 0.1 & -25.0 & 9.0 & 1.8 & 27.0 & 3.5 \\
\hline
\end{tabular}

${ }^{1} \bar{x}$ - average for the years $2005-2010, \Delta \%$ - average annual change in 2005-2010.

${ }^{2} 10.11$ - Processing and preserving of meat, 10.12 - Processing and preserving of poultry meat, 10.13 - Production of meat and poultry meat products, 10.20 - Processing and preserving of fish, crustaceans and mollusks, 10.31 - Processing and preserving of potatoes, 10.32 - Manufacture of fruit and vegetable juice, 10.39 - Other processing and preserving of fruit and vegetables, 10.41 - Manufacture of oils and fats, 10.42 - Manufacture of margarine and similar edible fats, 10.51 -Operation of dairies and cheese making, 10.52 - Manufacture of ice cream, 10.61 - Manufacture of grain mill products, starches and starch products, 10.71 - Manufacture of bread; fresh pastry goods and cakes, 10.72 - Manufacture of rusks and biscuits; preserved pastry goods and cakes, 10.73 - Manufacture of macaroni, noodles, couscous and similar farinaceous products, 10.81 - Manufacture of sugar, 10.82 - Manufacture of cocoa, chocolate and sugar confectionery, 10.83 - Processing of tea and coffee, 10.84 - Manufacture of condiments and seasonings, 10.85 - Manufacture of prepared meals and dishes, 10.86 - Manufacture of homogenised food preparations and dietetic food, 10.89 - Manufacture of other food products, 10.91 Manufacture of prepared animal feeds, 11.01 - Distilling, rectifying and blending of spirits, 11.02 - Manufacture of wine from grape, 11.03 - Manufacture of cider and other fruit wines, 11.04 - Manufacture of other non-distilled fermented beverages, 11.05 - Manufacture of beer, 11.06 - Manufacture of malt, 11.07 - Manufacture of soft drinks; production of mineral waters and other bottled waters.

Source: own calculations based on unpublished CSO data.

\section{Regression models}

This section of the article presents basic descriptive statistics of independent and dependent variables (Table 3)

\footnotetext{
2 Beta coefficients $(\beta)$ provide information about the relative significance of independent variables in explaining the variability in the dependent variable; Beta coefficients $(\beta)$ were calculated according to the formula
}

and the results of estimation of the parameters of regression models of the return on sales, operating assets and equity with beta coefficients $(\beta)^{2}$ (Tables $\left.4,5,6\right)$.

$\beta_{j}=\left(s_{j} \times a_{j}\right) / s_{y}$, where: $a_{j}-$ partial regression coefficient for independent variable, $s_{j}-$ standard deviation of independent variable, $s_{y}-$ standard deviation of dependent variable (Goldberger, 1966). 
On the basis of the data presented in Table 3 it is possible to notice that the distribution of branches of the food industry according to the total inventory cycle and discrete cycles was characterised by a slight right-skewed asymmetry $(\bar{x}>$ $Q_{2}$ ). This means that in the period under investigation the branches with shorter than average cycles prevailed. Moreover, it is possible to notice high variability of inventory cycles, especially in the semi-finished products and work-in-process cycle $(\mathrm{V}=111.4 \%)$ and in the finished products cycle $(\mathrm{V}=146.2 \%)$.

The distribution of the other independent variables was very similar to the normal distribution. Apart from the gross profit/operating profit ratio (EBTEBIT), it was characterised by low variability. On the one hand, this points to the fact that the level of cost effectiveness determined by material costs (VAOR) and payroll (EBITVA) was relatively stable in that period. On the other hand, this indicates a high and increasing influence of financial costs on the financial performance, which is strongly diversified in the system of branches of the food industry ( $\mathrm{V}=74.3 \%)$. This also means that branches of the food industry in Poland differ in their financial strategies and thus they are influenced by the financial leverage effect to different extents. This finding is largely supported by the return-onequity variability ratio (ROE), whose level was considerably higher than ROS and ROA, as it amounted to $\mathrm{V}=78.8 \%$.

Table 4 shows the coefficients of linear regression equations between the value of return on sales (ROS) and statistically significant independent variables $(p \leq 0.05)$. It also shows determination $\left(\mathrm{R}^{2}\right)$ and beta coefficients $(\beta)$ estimated on the basis of the data from the period of six years from 28 branches of the food industry (168 observations). In order to identify the strength and direction of the influence of inventory cycles on this profitability category six separate regression models were presented in Table 4.

Models 1-5 provide information about the individual influence of the total inventory cycle (model 1) and the influence of individual types of inventory (models 2-5). Model 6 contains the parameters of the function allowing for the simultaneous influence of the length of the cycles of individual types of inventory without the total inventory cycle. This procedure enables verification of the hypotheses about the influence of each of these cycles on the return on sales.

The analysis of the structural parameters of the presented regression models gives grounds for the conclusion that the assumed independent variables to a large extent accounted for the variability of the return on sales in all of the six regression models (74.7-92.0\%). The negative values of regression coefficients for the variables of the total inventory cycle (TINC), the raw material cycle (RMC) and the semi-finished products and work-in-process cycle (SFPC) definitely point to the negative influence of lengthening these inventory cycles on the return on sales in the food industry. On the other hand, the positive values of regression coefficients for the variables of the finished products cycle (FPC) and goods cycle (GC) point to the fact that lengthening of these types of inventory cycles is favourable for the food industry. There may be many causes of this situation. Nevertheless, it seems that the most important of them is the pursuit of maintenance of sales continuity. On the one hand, it favours meeting the demand at any time, and on the other hand, it enables enterprises to build a stable position on a market which is strongly competitive.

The simultaneous presence of all discrete inventory cycles (model 6) in the regression analysis points to the fact that the causes of improvement in the return on sales should mainly be sought in the reduced raw material cycle (RMC) as well as the semi-finished products and work-in-process cycle (SFPC) and in longer finished products cycle (FPC). However, it is mostly obvious that the other variables exerted the strongest and simultaneously positive influence on the return on sales. In view of the $\beta$ measure the variability in the return on sales was most strongly influenced by the payroll (EBITVA) and cost effectiveness, measured with the value added/revenue ratio (VAOR). Moreover, the positive value of the regression coefficient with the variable $\operatorname{ROS}_{\mathrm{t}-1}$, indicates a significant positive influence of the financial performance from earlier periods, i.e. the presence of the so-called halo effect. The influence of the aforementioned variables on the return on sales was several times greater than that of inventory cycles.

Table 5 shows the coefficients of linear regression equations between the value of return on operating assets (ROA) and statistically significant independent variables $(\mathrm{p} \leq 0.05)$. It also shows determination $\left(\mathrm{R}^{2}\right)$ and beta coefficients $(\beta)$ estimated on the basis of the data from the period of six years from 28 branches of the food industry (168 observations).

Similarly to the return on sales (ROS), in order to identify the strength and direction of the influence of inventory cycles on the return on operating assets (ROA) six regression models were presented in Table 5.

The analysis of the parameters of those models indicates that the adopted independent variables to a large extent accounted for the variability of the return on operating assets in all of the six regression models (77.7-82.2\%).

Negative values of regression coefficients for all the variables of inventory cycles clearly point to the fact that their lengthening was accompanied by a negative trend in the variability of return on assets. The negative influence of longer inventory cycles on the return on assets was much weaker than the positive influence of the other variables. Nevertheless, it is possible to notice that in view of the $\beta$ measure the variability in the return on operating assets was most negatively influenced by lengthening total inventory cycles $(\beta=-0.258)$, whereas it was least negatively influenced by lengthening the goods cycle $(\beta=-0.101)$. The negative influence of lengthening the other cycles was comparable.

The simultaneous presence of all discrete inventory cycles (model 6) in the regression analysis points to the fact that the causes of improvement in the return on operating assets (ROA) should mainly be sought in the reduced raw material cycle (RMC), the finished products cycle (FPC) and the goods cycle (GC). Moreover, when the other variables are taken into consideration, it is possible to notice that their influence on the return on operating assets (ROA) 
Zbigniew Golas, Anna Bieniasz. Empirical Analysis of the Influence of Inventory Management on Financial Performance...

was positive and much stronger than the negative influence of longer inventory cycles. On the basis of the $\beta$ measure it is possible to observe that the strength of the positive influence of the return on sales (ROS) and the so-called halo effect $\left(\mathrm{ROA}_{\mathrm{t}-1}\right)$ on the return on operating assets was about 3-4 times greater than the strength of the negative influence of the lengthening of individual inventory cycles.

Table 3

Descriptive statistics of regression models variables (2005-2010)

\begin{tabular}{|c|c|c|c|c|c|c|c|c|}
\hline Variables & $\bar{x}$ & $\mathbf{s}_{\mathrm{d}}$ & $\max$ & $\min$ & $\mathbf{Q}_{1}$ & $\mathbf{Q}_{2}$ & $\mathbf{Q}_{3}$ & $\mathbf{V}$ \\
\hline TINC & 86.8 & 46.7 & 302.0 & 18.8 & 52.8 & 83.1 & 111.3 & 53.8 \\
\hline RMC & 33.6 & 23.7 & 149.3 & 4.4 & 20.5 & 29.8 & 38.8 & 70.5 \\
\hline SFPC & 4.3 & 4.8 & 22.8 & 0.0 & 1.2 & 2.7 & 5.4 & 111.4 \\
\hline FPC & 15.2 & 22.2 & 136.1 & 1.0 & 5.6 & 8.4 & 14.5 & 146.2 \\
\hline GC & 33.7 & 27.8 & 229.3 & 2.4 & 15.4 & 26.8 & 44.9 & 82.6 \\
\hline EBITVA & 0.26 & 0.10 & 0.57 & 0.03 & 0.19 & 0.26 & 0.32 & 0.10 \\
\hline VAOR & 0.37 & 0.13 & 0.80 & 0.18 & 0.27 & 0.34 & 0.45 & 0.10 \\
\hline ICE & 1.29 & 0.22 & 2.73 & 1.05 & 1.16 & 1.26 & 1.34 & 16.9 \\
\hline EBTEBIT & 0.51 & 0.38 & 1.23 & -3.03 & 0.43 & 0.58 & 0.68 & 74.3 \\
\hline ROS & 8.8 & 3.7 & 22.4 & 2.1 & 5.8 & 8.5 & 11.2 & 2.7 \\
\hline ROA & 17.1 & 6.8 & 38.4 & 3.2 & 13.0 & 15.6 & 21.2 & 39.7 \\
\hline ROE & 16.7 & 13.2 & 66.8 & -73.9 & 9.7 & 16.4 & 23.8 & 78.8 \\
\hline
\end{tabular}

$\bar{x}$ - the mean value, $s_{d}$ - standard deviation, $\max$ - the maximum value, min - the minimum value, $Q_{l}-$ first quartile, $Q_{2}-$ median, $Q_{3}-$ third quartile, $V$ (\%) - coefficient of variation.

Variables: TINC - total inventory cycle, RMC - raw materials cycle, SFPC - semi-finished products and work in progress cycle, FPC - finished products cycle, GC - goods cycle, EBITVA - the ratio of operating profit (EBIT) to value-added (VA), VAOR - ratio of value added to operating revenues, ICE ratio of invested capital to equity, EBTEBIT - ratio of earnings before tax to earnings before interest and taxes, ROS - operating return on sales, ROA return on operating assets, ROE - return on equity

Source: own calculations based on unpublished CSO data.

Table 4

Regression models of operating return on sales (ROS)

\begin{tabular}{|c|c|c|c|c|c|c|}
\hline \multirow{2}{*}{ Variables $^{1}$} & \multicolumn{6}{|c|}{ Regression coefficients $^{2}$} \\
\hline & model 1 & model 2 & model 3 & model 4 & model 5 & model 6 \\
\hline TINC & $-0.005(0.006)$ & & & & & \\
\hline RMC & & $-0.026(0.000)$ & & & & $-0.020(0.000)$ \\
\hline SFPC & & & $-0.086(0.000)$ & & & $-0.078(0.000)$ \\
\hline FPC & & & & $0.008(0.006)$ & & $0.010(0.000)$ \\
\hline GC & & & & & $0.010(0.023)$ & \\
\hline EBITVA & $31.87(0.000)$ & $33.26(0.000)$ & $31.67(0.000)$ & $30.28(0.000)$ & $17.83(0.000)$ & $32.87(0.000)$ \\
\hline VAOR & $14.32(0.000)$ & $14.16(0.000)$ & $13.51(0.000)$ & $13.45(0.000)$ & & $13.54(0.000)$ \\
\hline $\operatorname{ROS}_{\mathrm{t}-1}$ & $0.24(0.000)$ & $0.22(0.000)$ & $0.23(0.000)$ & $0.26(0.000)$ & $0.54(0.000)$ & $0.22(0.000)$ \\
\hline Constant & $-6.22(0.000)$ & $-6.06(0.000)$ & $-5.93(0.000)$ & $-6.38(0.000)$ & $-0.78(0.008)$ & $-5.68(0.000)$ \\
\hline & & & $\beta$ coefficients & & & \\
\hline TINC & -0.073 & & & & & \\
\hline RMC & & -0.162 & & & & -0.126 \\
\hline SFPC & & & -0.109 & & & -0.099 \\
\hline FPC & & & & 0.049 & & 0.061 \\
\hline GC & & & & & 0.076 & \\
\hline EBITVA & 0.829 & 0.865 & 0.824 & 0.788 & 0.464 & 0.855 \\
\hline VAOR & 0.503 & 0.498 & 0.475 & 0.473 & & 0.476 \\
\hline $\operatorname{ROS}_{\mathrm{t}-1}$ & 0.229 & 0.218 & 0.220 & 0.256 & 0.519 & 0.211 \\
\hline & & Parameters o & ression model qua & ssessment $^{3}$ & & \\
\hline $\mathrm{R}^{2}$ & 89.4 & 91.4 & 90.0 & 89.1 & 74.7 & 92.0 \\
\hline $\mathrm{F}$ & 352.3 & 442.5 & 376.9 & 343.1 & 166.84 & 322.9 \\
\hline$\delta$ & 1.2 & 1.1 & 1.1 & 1.1 & 1.8 & 1.1 \\
\hline
\end{tabular}

${ }^{1}$ Independent variables: TINC - total inventory cycle, RMC - raw materials cycle, SFPC - semi-finished products and work in progress cycle, FPC - finished products cycle, GC - goods cycle, EBITVA - the ratio of operating profit to value-added, VAOR - ratio of value added to operating revenues, ROS $\mathrm{t}_{\mathrm{t}-1}$ operating return on sales in year $\mathrm{t}-1(\%)$.

${ }^{2}$ Placed at the regression coefficients the values in parentheses provide information on the significance of independent variables $(p \leq 0,05)$.

${ }^{3} R^{2}$ - adjusted coefficient of determination in $\%, F$ - Snedecora statistics, $\delta$ - standard error.

Source: own calculations. 
Regression models of return on assets (ROA)

\begin{tabular}{|c|c|c|c|c|c|c|}
\hline \multirow{2}{*}{ Variables $^{1}$} & \multicolumn{6}{|c|}{ Regression coefficients $^{2}$} \\
\hline & model 1 & model 2 & model 3 & model 4 & model 5 & model 6 \\
\hline TINC & $-0.038(0.000)$ & & & & & \\
\hline $\mathrm{RMC}$ & & $-0.037(0.000)$ & & & & $-0.051(0.000)$ \\
\hline SFPC & & & $-0.200(0.000)$ & & & \\
\hline FPC & & & & $-0.048(0.000)$ & & $-0.062(0.000)$ \\
\hline GC & & & & & $-0.025(0.008)$ & $-0.022(0.009)$ \\
\hline ROS & $1.13(0.000)$ & $0.97(0.000)$ & $0.95(0.000)$ & $1.06(0.000)$ & $0.97(0.000)$ & $1.18(0.000)$ \\
\hline $\mathrm{ROA}_{\mathrm{t}-1}$ & $0.32(0.000)$ & $0.44(0.000)$ & $0.42(0.000)$ & $0.40(0.000)$ & $0.44(0.000)$ & $0.29(0.000)$ \\
\hline Constant & $4.88(0.000)$ & $2.15(0.010)$ & $2.32(0.006)$ & $1.69(0.027)$ & $1.74(0.037)$ & $4.97(0.000)$ \\
\hline & & & $\beta$ coefficients & & & \\
\hline TINC & -0.258 & & & & & \\
\hline $\mathrm{RMC}$ & & -0.130 & & & & -0.179 \\
\hline SFPC & & & -0.141 & & & \\
\hline FPC & & & & -0.156 & & -0.202 \\
\hline GC & & & & & -0.101 & -0.089 \\
\hline ROS & 0.631 & 0.542 & 0.528 & 0.588 & 0.539 & 0.659 \\
\hline $\mathrm{ROA}_{\mathrm{t}-1}$ & 0.314 & 0.437 & 0.418 & 0.391 & 0.438 & 0.291 \\
\hline & & Parameters & gression model qu & assessment $^{3}$ & & \\
\hline $\mathrm{R}^{2}$ & 81.7 & 78.3 & 78.5 & 78.7 & 77.7 & 82.2 \\
\hline $\mathrm{F}$ & 249.7 & 202.4 & 204.1 & 206.5 & 194.6 & 154.8 \\
\hline$\delta$ & 2.9 & 3.1 & 3.1 & 3.1 & 3.2 & 2.8 \\
\hline
\end{tabular}

${ }^{1}$ Independent variables: TINC - total inventory cycle, RMC - raw materials cycle, SFPC - semi-finished products and work in progress cycle, FPC - finished products cycle, GC - goods cycle, ROS - operating return on sales $(\%)$, ROA - return on assets in year t-1 (\%).

${ }^{2}$ Placed at the regression coefficients the values in parentheses provide information on the significance of independent variables $(p \leq 0,05)$.

${ }^{3} R^{2}$-adjusted coefficient of determination in $\%, F$ - Snedecora statistics, $\delta$ - standard error.

Source: own calculations

Table 6 shows the coefficients of linear regression equations between the value of return on equity (ROE) and statistically significant independent variables $(\mathrm{p} \leq 0.05)$.

The negative values of regression coefficients for all the variables of individual inventory cycles definitely point to the fact that their lengthening was accompanied by a negative trend in the variability of return on equity (ROE). Moreover, the negative influence of extending inventory cycles on the return on equity was much weaker than the positive influence of the other variables. In view of the $\beta$ measure the variability in the return on equity was most negatively influenced by lengthening total inventory cycles (TINC, $\beta=-0.139$ ) and the raw material cycle (RMC, $\beta=-0.109$ ), whereas the influence of the lengthening of the other cycles was comparable and relatively less negative.

It also shows determination $\left(\mathrm{R}^{2}\right)$ and beta coefficients $(\beta)$ estimated on the basis of the data from the period of six years from 28 branches of the food industry (168 observations). Similarly to the return on sales (ROS) and the return on operating assets (ROA), in order to identify the strength and direction of the influence of inventory cycles on the return on equity (ROE) six regression models were presented in Table 6 .

The analysis of the model parameters (Table 6) indicates that the assumed independent variables to a large extent explained the variability of return on equity (ROE) in all of the six regression models (78.7-80.2\%). The simultaneous presence of all discrete inventory cycles (model 6) in the regression analysis points to the fact that the causes of improvement in the return on equity should mainly be sought in the reduced raw material cycle and the finished products cycle.

The influence of the other variables on the return on equity (ROE) was positive, but it was not always much stronger than the negative influence of lengthening inventory cycles. When the values of the $\beta$ measure are taken into consideration, it is possible to observe that the main determinant of the return on equity is financial costs (EBTEBIT), which is followed by the return on sales (ROS) and the financial performance from earlier periods $\left(\mathrm{ROE}_{\mathrm{t}-1}\right)$. The return on equity (ROE) was also positively influenced by the equity multiplier (ICE). However, its influence on the ROE was low and, as far as the absolute value is concerned ( $\beta=0.081-0.108)$, it was comparable with the negative influence of lengthening inventory cycles. In general, this means that in the food industry the financial structure did not significantly contribute to the leverage rate of return on equity. 
Regression models of return on equity (ROE)

\begin{tabular}{|c|c|c|c|c|c|c|}
\hline \multirow{2}{*}{ Variables $^{1}$} & \multicolumn{6}{|c|}{ Regression coefficients $^{2}$} \\
\hline & model 1 & model 2 & model 3 & model 4 & model 5 & model 6 \\
\hline TINC & $-0.040(0.000)$ & & & & & \\
\hline RMC & & $-0.061(0.002)$ & & & & $-0.067(0.000)$ \\
\hline SFPC & & & $-0.228(0.014)$ & & & \\
\hline FPC & & & & $-0.036(0.018)$ & & $-0.047(0.024)$ \\
\hline $\mathrm{GC}$ & & & & & $-0.035(0.028)$ & \\
\hline ROS & $1.08(0.000)$ & $1.01(0.000)$ & $0.98(0.000)$ & $1.07(0.000)$ & $1.02(0.000)$ & $1.08(0.000)$ \\
\hline ICE & $5.34(0.025)$ & $5.10(0.028)$ & $6.34(0.001)$ & $6.51(0.008)$ & $6.47(0.008)$ & $4.83(0.017)$ \\
\hline EBTEBIT & $23.33(0.000)$ & $23.59(0.000)$ & $23.51(0.000)$ & $23.21(0.000)$ & $23.78(0.000)$ & $23.06(0.000)$ \\
\hline $\mathrm{ROE}_{\mathrm{t}-1}$ & $0.21(0.000)$ & $0.23(0.000)$ & $0.22(0.000)$ & $0.22(0.000)$ & $0.23(0.000)$ & $0.21(0.000)$ \\
\hline Constant & $-11.54(0.003)$ & $-12.53(0.001)$ & $-14.82(0.000)$ & $-16.13(0.000)$ & $-15.31(0.000)$ & $-11.41(0.004)$ \\
\hline & & & $\beta$ coefficients & & & \\
\hline TINC & -0.139 & & & & & \\
\hline RMC & & -0.109 & & & & -0.121 \\
\hline SFPC & & & -0.083 & & & \\
\hline FPC & & & & -0.061 & & -0.079 \\
\hline GC & & & & & -0.075 & \\
\hline ROS & 0.309 & 0.287 & 0.282 & 0.308 & 0.291 & 0.311 \\
\hline ICE & 0.088 & 0.084 & 0.105 & 0.108 & 0.107 & 0.081 \\
\hline EBTEBIT & 0.665 & 0.673 & 0.671 & 0.662 & 0.678 & 0.658 \\
\hline $\mathrm{ROE}_{\mathrm{t}-1}$ & 0.201 & 0.227 & 0.217 & 0.217 & 0.223 & 0.208 \\
\hline & & Parameters & ression model qua & assessment ${ }^{3}$ & & \\
\hline $\mathrm{R}^{2}$ & 80.2 & 79.5 & 78.9 & 78.7 & 78.8 & 79.9 \\
\hline $\mathrm{F}$ & 136.3 & 130.5 & 126.5 & 124.1 & 125.8 & 111.9 \\
\hline$\delta$ & 4.8 & 4.9 & 5.1 & 5.1 & 5.0 & 4.9 \\
\hline
\end{tabular}

${ }^{1}$ Independent variables: TINC - total inventory cycle, RMC - raw materials cycle, SFPC - semi-finished products and work in progress cycle, FPC - finished products cycle, GC - goods cycle, ROS - operating return on sales (\%), ICE - ratio of invested capital to equity, EBTEBIT - ratio of earnings before tax to earnings before interest and taxes, $\mathrm{ROE}$ - return on equity in year $\mathrm{t}-1(\%)$.

${ }^{2}$ Placed at the regression coefficients the values in parentheses provide information on the significance of independent variables $(p \leq 0,05)$.

${ }^{3} R^{2}$-adjusted coefficient of determination in $\%, F$ - Snedecora statistics, $\delta$ - standard error.

Source: own calculations.

\section{Conclusions}

The maintenance of inventory by enterprises results from numerous premises, such as: the need to ensure rhythmicity of production, economies of scale of production and supplies, reduced risk related to the uncertainty of supplies and delivery time, pursuit of limiting the influence of seasonality of supplies and seasonality of demand, ensuring sales continuity. However, the maintenance of inventory involves bearing various types of real costs related to its maintenance and ordering as well as opportunity costs. Thus, this means that inventory management is directly correlated with financial effectiveness of enterprises and it should be subject to optimisation. As results from the research on the branches of the food industry in Poland, improvement in the management effectiveness, measured with the length of inventory cycles, may be an important source of improvement in the financial performance. The estimated parameters of regression models indicate that in the food industry shortening inventory cycles usually resulted in higher profitability. This also means that the rationalisation of inventory management contributes to the achievement of one of the most frequently mentioned business goals today, which is the increase in the value for the owners.

The obtained results are generally convergent with the results of studies conducted in other countries. However, such analyses in the Polish economy had a limited character due to among others the short period of functioning in the market system and limited access to statistical databases of industry. The process of integration with the European Union will definitely favour the intensification of research on the effectiveness of inventory management, because in a way it naturally enforces rationalisation of inventory management and designates new directions of research in this area. It appears that the analysis based on the example of the Polish food sector will be an inspiration to other studies. 


\section{References}

BACH. (2011). Bank for Accounts of Companies Harmonised. The European database of aggregate information on nonfinancial corporations. European Central Bank. Available from Internet: http://www.bachesd.banque-france.fr

Brigham, E. F., Gapenski, L. C. (1993). Intermediate Financial Management. Dryden Press, New York.

Cannon, A. R. (2008). Inventory improvement and financial performance. International Journal of Production Economics 115(2), 581-593. Available from Internet: http://dx.doi.org/10.1016/j.ijpe.2008.07.006

Capkun, V.; Hameri, A. P., Weiss, L. A. (2009). On the relationship between inventory and financial performance in manufacturing companies. International Journal of Operations \& Production Management, 29(8), 789-806. Available from Internet: http://dx.doi.org/10.1108/01443570910977698

Chen, H., Frank, M. Z., \& Wu, O. Q. (2005). What actually happened to the inventories of American companies between 1981 and 2000?. Management Science, 51(7), 1015-1031. Available from Internet: http://dx.doi.org/10. 1287/mnsc. 1050.0368

Chan, K., \& Chen, N. (1988). An unconditional asset-pricing test and the role of firm size as an instrumental variable for risk. Journal of Finance, 43(2), 309-325. Available from Internet: http://dx.doi.org/10.1111/j.1540-6261.1988. tb03941.x

Deloof, M. (2003). Does working capital management affect profitability of Belgian firms?. Journal of Business Finance \& Accounting, 30(3/4), 573-588. Available from Internet: http://dx.doi.org/10.1111/1468-5957.00008

Dong, H.P.; Su, J. (2010). The relationship between working capital management and profitability: a Vietnam case. International Research Journal of Finance and Economics, 49, 59-67.

Eroglu, C.; Hofer, C. (2011). Inventory types and firm performance: vector autoregressive and vector error correction models. Journal of Business Logistics, 32(3), 227-239. Available from Internet: http://dx.doi.org/10.1111/j.21581592.2011.01019.x

Gaur, V., Fisher, M. L., \& Raman, A. (2005). An econometric analysis of inventory turnover performance in retail services. Management Science, 51(2), 181-194. Available from Internet: http://dx.doi.org/10.1287/mnsc.1040.0298

Goldberger, A. S. (1966). Econometric theory. John Wiley \& Sons, New York.

Hawawini, G., \& Viallet, C. (2002). Finance for Executives. Managing for Value Creation. Thomson Learning, SouthWestern.

Kempny, D. (1995). Koszty zapasow. Gospodarka Materialowa i Logistyka, 7/8 [Cost of inventories. Materials Management and Logistics, 7/8], (in Polish).

Kisperska-Moron, D. (1995). Czynniki ksztaltujace poziom i strukture zapasow w przedsiebiorstwach. Gospodarka Materialowa $i$ Logistyka, $\mathrm{nr} 11$ [Factors affecting the level and inventories structure in companies. Materials Management and Logistics, 11], (in Polish).

Kolias, G. D., Dimelis, S. P., \& Filios, V. P. (2011). An empirical analysis of inventory turnover behaviour in Greek retail sector: 2000-2005. International Journal of Production Economics, 133(1), 143-153. Available from Internet: http://dx.doi.org/10.1016/j.ijpe.2010.04.026

Koumanakos, D. P. (2008). The effect on inventory management on firm performance. International Journal of productivity and Performance Management, 57(5), 355-369. Available from Internet: http://dx.doi.org/10.1108/1741040 0810881827

Lazaridis, I., \& Tryfonidis, D. (2006). Relationship between working capital management and profitability of listed companies in the Athens stock exchange. Journal of Financial Management and Analysis, 19(1), 26-35. Available from Internet: http://papers.ssrn.com/sol3/papers.cfm?abstract_id=931591

Obermaier, R., \& Donhauser, A. (2009). Disaggregate and aggregate inventory to sales ratios over time: the case of German corporations 1993-2005. Logistics Research, 1, 95-111. Available from Internet: http://dx.doi.org/10.1007/s12159009-0014-9

Padachi, K. (2006). Trends in working capital management and its impact on firms' performance: An analysis of Mauritian small manufacturing firms. International Review of Business Research Papers, 2(2), 45-58. Available from Internet: http://www.bizresearchpapers.com/Kesseven.pdf

Polish Classification of Activities (PKD 2007). (2011). Central Statistical Office, Warsaw. Available from Internet: http://www.stat.gov.pl

Raheman, A., Qayyum, A., Afza, T., \& Bodla, M. A. (2010). Sector-wise Analysis of Working capital Management and Firm Performance in Manufacturing Sector of Pakistan. Interdisciplinary Journal of Contemporary Research in Business, 2(7), 412-437. Available from Internet: http://ijcrb.webs.com/archives.htm

Ramachandran, A., \& Janakiraman, M. (2009). The Relationship between working capital management efficiency and EBIT. Managing Global Transitions, 7(1), 61-74. Available from Internet: http://www.fm.upr.si/zalozba/ISSN/1581-6311/71.pdf\#page $=63$ 
Zbigniew Golas, Anna Bieniasz. Empirical Analysis of the Influence of Inventory Management on Financial Performance...

Roumiantsev, S., \& Netessine, S. (2007). What can be learned from classical inventory models?: a cross-industry exploratory investigation. Manufacturing and Service Operations Management, 9(4), 409-429. Available from Internet: http://dx.doi.org/10.1287/msom.1070.0166

Shah, R., \& Shin, H. (2007). Relationships among information technology, inventory and profitability: an investigation of level invariance using sector level data. Journal of Operations Management, 25(4), 768-84. Available from Internet: http://dx.doi.org/10.1016/j.jom.2007.01.011

Sierpinska, M., \& Wedzki, D. (1997). Zarzadzanie plynnoscią finansową w przedsiebiorstwie. PWN, Warszawa. [Liquidity management in the enterprise. PWN, Warsaw], (in Polish).

Sine, W. D., Shane, S., \& Di Gregorio, D. (2003). The halo effect and technology licensing: the influence of institutional prestige on the licensing of university inventions. Management Science, 49(4), 478-96. Available from Internet: http://dx.doi.org/10.1287/mnsc.49.4.478.14416

The article has been reviewed.

Received in December, 2013; accepted in June, 2016. 